\title{
In memory of
}

Iris Mary (née Theuma) Mangion (1934-2017)

Eva Bourgeois (1907-1985) 
Carmen Mangion - 9781526140470

Downloaded from manchesterhive.com at 04/26/2023 11:58: 09AM 